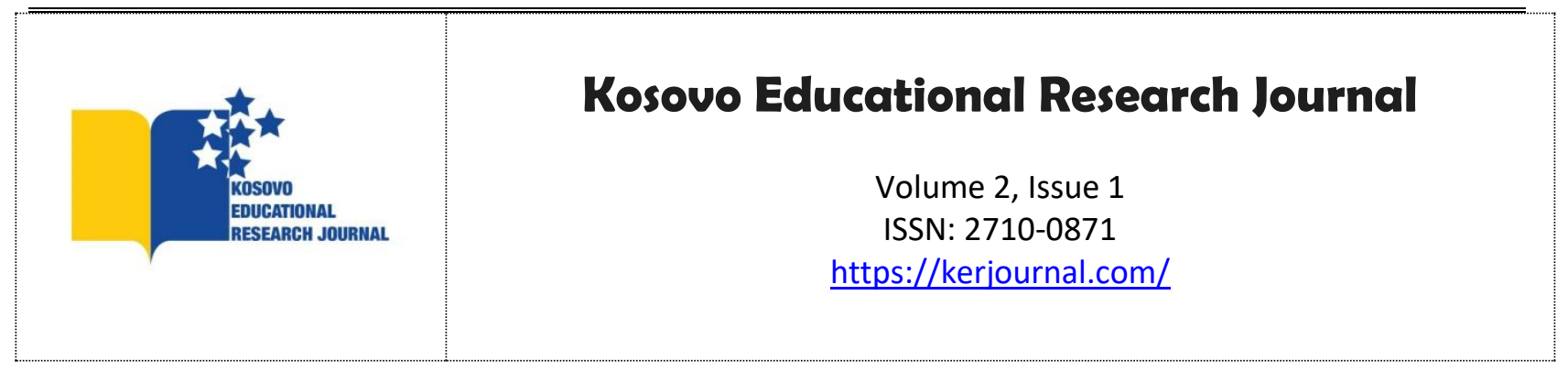

\title{
Safahat’ta Öğretim İlke ve Yöntemlerinden Örnek Olay Yöntemi
}

\author{
Cem TUNA*
}

Recep Tayyip Erdoğan Üniversitesi, TÜRKIYE

\begin{abstract}
Özet: İstiklal Marşı şairimiz Mehmet Akif Ersoy’un temel eseri, çeşitli zamanlarda yazdığ şiirleri toplayan ve yedi kitaptan oluşan Safahat'tır. Toplumsal sorunların ele alındığı bu eserde üzerinde durulan konulardan biri eğitim ve öğretimdir. Bu çalışmada hem örgün hem de yaygın bir eğitimci olan Mehmet Akif' in şiirlerinde öğretim ilke ve yöntemlerinden örnek olay yöntemi incelenmiştir. Mehmet Akif çevresinde gözlemlerini, başından geçenleri ve hikâyeleri betimler. Çocuk psikolojisi, çocuğun gelişim dönemlerini bilme, ona göre davranma, çocuğun düzeyine uygunluk, çocuğu güdüleme konuları üzerinde durur. Eğitimde verilmesi gereken değerler olarak, çalışma, ümitli olma, azim, çaba, gayret, yardımlaşma, cesaret, iyilik gibi konuları işler. Eğitimde imkân ve fursat eşitliği, genellik ve eşitlik, ferdin ve toplumun ihtiyaçları, eğitim hakkı, eğitimde yöneltme, bilimsellik, her yerde eğitim, süreklilik, şiddetin olmaması ilkelerini savunur. Eğitimin genel amaçları arasında kişilikli insan yetiştirme, vatandaşlık eğitimi ve meslek sahibi birey yetiştirmeyi ele alır. Eğitimde ideal insan modeli olarak Asım gibi bir gençlik yetiştirmek ister. Eleştirel düşünme, yansıtıcı düşünme ve yaratıcı düşünme becerileri kazanmayı ve problem çözme yöntemini kullanır. Osmanlı Devleti’nin eğitim sistemini eleştirir. Okulların günün şartlarına uymadığını, yeni okul sistemlerinin getirilmesini önerir. Okul programlarının eskidiğinin, teorik kaldığını, uygulamadan uzak kaldığını saptar. Uygulamalı, fen bilimlerine dayalı, güncel, dini, milli ve ahlaki programlar önerir. Ders kitaplarının güncel, düzeye uygun, bilimsel yazılmasını ister. Halk eğitimini önemser. Aile eğitiminde anne ve babanın eğitimi üzerinde durur. Halkı bilinçlendirmeden, aileyi eğitmeden ilerlemenin, gelişmenin mümkün olamayacağını belirtir. Camilerin eğitim yuvası olduğunu, halkın camilerdeki eğitimle eğitilebileceğini vurgular. Cehaletle savaşılmasını dile getirir. Öğretmenlerin imanlı, edepli, liyakatli ve vicdanlı olmasını benimseyerek öğretmen yeterliliklerini ortaya koyar. İdeal öğretmen yetiştirilmesini ileri sürer.

Mehmet Akif Ersoy’un Safahat adlı eserinde ileri sürdüğü eğitim görüşleri, günümüz Türkiye'si ve Türk Dünyası için ışık olacaktır. Çalışma sonuç ve önerilerle son bulmaktadır.

Anahtar Kelimeler: Mehmet Akif Ersoy, Safahat, Öğretim İlke ve Yöntemleri, Örnek Olay Yöntemi, Eğitim Psikolojisi.

To cite this article: Tuna, C. (2021). Safahat'ta Öğretim İlke ve Yöntemlerinden Örnek Olay Yöntemi. Kosovo Educational Research Journal, 2(1). 36-54.
\end{abstract}




\title{
Case Study Method from Teaching Principles and Methods in Safahat
}

\author{
Cem TUNA* \\ Recep Tayyip Erdoğan Üniversity, TURKEY
}

\begin{abstract}
The basic work of our Turkish National Anthem poet Mehmet Akif Ersoy is Safahat, which collects poems he wrote at various times and consists of seven books. One of the issues emphasized in this work that deals with social problems is education and training. In this study, the Case Study Method, one of the Teaching Principles and Methods, in the poems of Mehmet Akif, who is both a formal and non-formal educator, has been examined. Describes his observations, experiences and stories around Mehmet Akif. It focuses on child psychology, knowing the developmental stages of the child, acting accordingly, conforming to the child's level, and motivating the child. As the values that should be given in education, it deals with issues such as work, hope, perseverance, effort, effort, cooperation, courage and kindness. It defends the principles of equality of opportunity and opportunity in education, generality and equality, the needs of the individual and society, the right to education, orientation in education, scientificity, education everywhere, continuity, and the absence of violence. Among the general purposes of education, it deals with the training of people with a personality, citizenship education and raising individuals with a profession. He wants to raise a youth like Asim as the ideal human model in education. Use the problem solving method and gain critical thinking, reflective and creative thinking skills. He criticizes the education system of the Ottoman State. It suggests that schools do not comply with the conditions of the day, and that new school systems be introduced. It determines that school programs are old, theoretical and far from implementation. Suggests applied, science-based, current, religious, national and moral programs. He wants the textbooks to be written up to date, appropriate to the level, and scientifically. It cares about public education. It focuses on the education of mother and father in family education. He states that without raising public awareness and educating the family, it is not possible to progress and develop. He emphasizes that mosques are homes of education and that the public can be educated through education in mosques. It expresses the fight against ignorance. It demonstrates the teacher competencies by embracing the teachers to be faithful, decent, competent and conscientious. It promotes the training of ideal teachers.

Mehmet Akif Ersoy training views put forward by Safahat in his work today will be light for Turkey and the Turkish world. The study ends with results and suggestions.

Keywords: Mehmet Akif Ersoy, Safahat, Teaching Principles and Methods, Case Study Method, Educational Psychology.
\end{abstract}

\section{Giriş}

Bu çalışmada İstiklal Marşı şairimiz Mehmet Akif Ersoy’un şiirlerini topladığı Safahat adlı eserinde günümüz eğitimine yansıyan görüşlerinde örnek olay yöntemi incelenmiştir. Mehmet Akif döneminin en önemli fikir ve edebiyat önderlerindendir. Yaşadığı zorlu dönemde ilmek ilmek dizeleriyle, yazılarıyla mücadele vermiş, problemler üzerinde kafa yormuş, çözüm 
önerileri getirmiştir. O, dert sahibidir, İslam ve Türk Dünyası'nın, İslam coğrafyasının içine düşmüş olduğu acı, buhranlı durumu, ruhunun derinliklerinde hissetmiş, yudum yudum yaşamış ve eserleriyle okuyuculara yaşatmıştır.

Kaplan'a göre (2012, 175); Türk edebiyatında onun kadar içinde yaşadığ 1 devri bütün ayrıntısıyla gören ve gösteren başka bir şair yoktur, denilebilir. Safahat adeta, belirli bir açıdan bakılarak betimlenen bir manzum romana benzemektedir. Sokak, ev, kulübe, saray, meyhane, camii, köy, şehir, fakir, zengin, dindar, dinsiz, cılız, pehlivan, korkak, kahraman, halk, yüksek tabaka, aydın, cahil, yerli, yabancı vardır. Doğu, Batı, Avrupa, Asya, ticaret, siyaset, savaş, barış, şehircilik, köycülük, geçmiş, bu gün, gelecek, hayal, gerçek, hemen hemen her şey Mehmet Akif' in duyuş ve görüş sahnesine girer. O bunları şiir olduğu kadar edebiyatın bütün ifade araçları ile yapar: Tasvirler yapar, portreler çizer, hikâyeler söyler, fikralar anlatır, konuşmalara başvurur, vaaz verir. Komik, trajik, öğretici, hamasi, lirik, hakimane, her edayı, her tonu kullanır. $\mathrm{Bu}$ suretle Akif şiirin sınırlarını hayatın kendisi yapar (Kaplan, 2012, 175). Kendi ifadesi ile "her ne demişse görüp de söylemiştir” (Kaçar, 1989, 5).

Mehmet Akif'in eğitimci yönü vardır. Eğitimdeki ve eğitime yansıyan toplumsal problemler, bu problemlerin temelleri, örgün eğitimin bir takım konularına yönelik görüşleri, gençliğin ve toplumun eğitimi konusundaki fikirleri önemlidir. Bir süre lise ve üniversite hocalığa da yapmış olan Mehmet Akif, gençliğe ve milletine bir rehber, bir 1şık olmuştur. Denilebilir ki gençliğin ve halkın eğitimi konusunda O'nun kadar duyarlı ve gerçekçi bir ikinci mütefekkir/ düşünce insanı yoktur (Kaçar, 1989, 3-4).

Kendi ülkesi ve İslam Dünyasının geri kalmasının nedenlerini tek tek saptamış ve tutarlı bir biçimde çözüm önerileri getirmiştir. Derdi bulmuş, bir çıkış yolu olarak dermanı göstermiştir (Kaçar, 1989, 5). O’nun ileri sürdüğü eğitim görüşleri günümüz Türk Dünyasını, İslam Dünyasını ilgilendirmektedir ve eğitim felsefelerine, eğitim politikalarına yön verecek mahiyet taşımaktadır.

Mehmet Akif, ailesine düşkündür, Safahatı oğlu Mehmet Ali'ye ithaf etmiştir. Safahatta okuyucuya seslenir, okuyucu ile iletişime geçer, ilişki kurar ve Oku! Der (Ersoy, 1984, 3). Bu emir bize Kur'an'ın ilk emrini hatırlatır. Tıpkı İstiklal Marşı’nın Korkma! Hitabında olduğu gibi. Orada da La tanzen (Üzülme) ayetini hatırlattığı gibi (Tevbe, 40- Karaman vd., 2006). Akif 
yazdıklarının yürekten olduğunu belirtir. Samimi bir ortam oluşturur. Bir sıcaklık ile O'nun gönül dünyasını merak ederek kitaba başlanır.

Oku, şayed sana bir hisli yürek lazımsa;

Oku, zira onu yazdım, iki söz yazdımsa. (Ersoy, 1984, 3)

Bir eğitimci olarak Mehmet Akif öğretim ilke ve yöntemlerinden örnek olay yöntemini kullanmıştır. Örnek olay yöntemi; gerçek yaşamdan alınan ya da kurmaca problemler, öykülemelerle öğrenme sürecini zenginleştiren ve öğrenenlerin bilgiyi anlamlandırması, yapılandırması için kullanılan bir yöntemdir (Kösterelioğlu, 2018, 129; Kara, 2014, 105). Öğrencilerde problem çözme, tartışma, empati, kritik düşünme ve yaratıcıllı̆̆ geliştirir, gerçek ve aktif öğrenmeyi sağlar (Tan, 2006, 121; Kara, 2014, 105). Genellikle istenmeyen durumları yansıtan problemlerin nedenlerine yönelik çözüm yolları üretmek için kullanılır (Savaş, 2014, 163). Soyut düşüncelerin somut durumlara uygulanması yöntemin amaçları arasındadır. Mevcut konuya yoğunlaşma, etkin çalışma, bilişsel ve duyuşsal alanları geliştirme avantajlarına sahiptir. Örnek olayın açık ve gerçekçi olmaması yöntemin dezavantajları arasındadır (Hesapçıoğlu, 1998, 224). Yöntemin uygulanmasında sınıf ortamına gerçek, yaşanmış ya da yaşanması muhtemel bir olay getirilir. Sorun odaklı konu ve olay öğrencilerle birlikte masaya yatırılarak incelenir. Öğrenci merkezli olan yöntemde örnek olay tartış1ır, sorulara cevap aranır. Örnek olayın çözümü/ analizi ile ilgili elde edilen sonuçlar özetlenerek ortak bir çıktıya ulaşılır (Cengizhan, 2015, 267). Mehmet Akif'in örnek olay yöntemini şiirlerinde başarılı bir biçimde kullandığı belirtilebilir. Eksik olan öğrencilerle yüz yüze çalışmanın olmamasıdır. Şiir yoluyla eğitimde bu okuyucuyu düşündürmek, hissettirmek, mesajlar vermek, kazanımlar kazandırmak şeklinde olmaktadır. Örnek olay yöntemi, etkili öğretim yöntemlerindendir (Borich, 2017).

$\mathrm{Bu}$ çalışmada Safahat'ta Mehmet Akif Ersoy'un günümüz eğitimine yansıyan görüşlerinde örnek olay yöntemi incelenmiştir. Bu amaçla aşağıdaki araştırma sorularına cevap aranmıştır:

1-Safahatta çocuk gelişimi ve eğitimi ile ilgili örnek olaylar nelerdir?

2-Safahatta değerler eğitimi ile ilgili örnek olaylar nelerdir?

3-Safahatta Türk Milli Eğitimin Temel İlkeleri ile ilgili örnek olaylar nelerdir? 


\section{Yöntem}

Safahatın günümüz eğitimine yansıyan görüşlerinde örnek olay yönteminin incelendiği çalışmanın verileri doküman incelemesi yoluyla toplanmıştır. Çalışmada Mehmet Akif Ersoy’un eseri olan Safahatın bütün şiirleri okunmuştur. Safahat olarak Ömer Rıza Doğrul'un hazırladığ1 İnkılap ve Aka Yayınevleri tarafından yayınlanan eser esas olarak alınmıştır (Ersoy, 1984). Beyan Yayınları tarafından günümüz Türkçesi ile hazırlanan eserden de yararlanılmıştır (Akbaş, 2013). Çocuk gelişimi ve eğitimi, değerler eğitimi ve Türk milli eğitimin temel ilkeleri ile ilgili görülen dizeler bulgu olarak tespit edilmiş, elde edilen bulgulara nitel veri analizlerinden içerik analizi yapılmıştır. İçerik analizinde temel amaç, toplanan verileri açıklayabilecek kavramlara ve ilişkilere ulaşmaktır (Yıldırım- Şimşek 2008, 227). Bu amaçla toplanan veriler önce öğretim ilke ve yöntemleri örnek olayı olarak kavramsallaştırılmış, daha sonra tümevarıma dayalı olarak düzenlenmiş ve buna göre veriyi açıklayan temalar saptanmıştır. Verilerin içindeki saklı olabilecek gerçekler ortaya konulmuştur.

\section{Bulgular ve Yorum}

$\mathrm{Bu}$ bölümde Safahatta çocuk gelişimi ve eğitimi, değerler eğitimi ve Türk milli eğitimin temel ilkeleri ile ilgili görülen dizeler, bulgular şeklinde ortaya konulmuş ve yorumlanmıştır.

\section{1.Çocuk Gelişimi ve Eğitimi İle İlgili Örnek Olaylar}

Mehmet Akif Ersoy Safahat adlı eserinde örnek olay yöntemini kullanarak başından geçen bir hatırasını anlatır. Fatih Cami adlı şiirinde kendisi 8 yaşında iken babasının kendisi ve kardeşini yatsı namazına Fatih Camiine götürmesini anlatır. Babası namaza durunca küçük Akif, camide ‘âşıkane' koşarmış.

Dalar giderdi. Ben artık kalınca âzâde , Ne âşıkâne koşardım hasırlar üstünde! (Ersoy, 1984, 8)

Başka bir baba kızını getirmiş, başka bir yerde ise küçük erkek çocuk. Koşar, koşar, durmazlar. Âmin denildikten sonra onları babaları onları alır, küçük erkek çocuk elinde feneri tutarak evlerine gider, yorulurlar ve mutlu bir şekilde uykuya dalarlar.

Bu olay Mehmet Akif 1873 doğum tarihli olduğuna göre yaklaşık 1881-2 yıllarıdır. Camide çocuklar koşmakta, ses çıkarmakta, bu gayet normal karşılanmaktadır. Uyarı, şiddet 
bulunmamaktadır. Bundan yaklaşık 137 yıl sonra 2019 yılında Türkiye Diyanet İşleri Başkanlığı yaz Kur’an kursları için şu sloganı seçmiştir:

Camide çocuk sesi

Vatanımın neşesi

Mehmet Akif’in o dönemki yaşantısı, günümüzde ulaşılmak istenen bir yaşantı olduğu belirtilebilir.

Bayram şiirinde, bayramın özel günler olduğu, çocukların yüzlerin güldüğü, çocukların oyun oynadıkları, oyuncaklarla eğlendikleri, yiyip-içtikleri günler olduğunu vurgular. Çocukların gönüllerince eğlendikleri, mutlu oldukları zamanlardır. Bu arada salıncağa parası olmadığı için binemeyen ve ağlayan yetim kız için oradan geçenler salıncakçıya rica eder, rica kabul ediliyor ve kız çocuğu parasız salıncaya biner, ağlaması kesilir.

Çocuk değil mi? "Salıncak!” diyor...

- Salıncakçı!

Kuzum biraz da bu binsin... Ne var sevâbına say.

Yetim sevindirenin ömrü çok olur...

- Hay hay!

Hemen o kız da salıncakçının mürüvvetine,

Katıldı ă̆lamayan kızların şetâretine. (Ersoy, 1984, 52)

Burada çocukların oyun, eğlenme hakkı, mutlu olma, mutlu bir çocukluk geçirme durumları söz konusudur. Bu ortamı oluşturmak için toplumda herkes üzerine düşeni yapacaktır. Ayrıca maddi imkândan mahrum olanlar da bir şekilde desteklenecektir.

Selma şiirinde 4 yaşında ölen kız kardeşini anlatır. Hastalık ve ölümün imtihan olduğunu, anne kalbinin buna dayanamadığını belirtir.

Ne zâlim illet imiş, bir çocukla uğraşıyor...

O olmasaydı da ben keşke hasta olsaydım. (Ersoy, 1984, 57)

Anneye sabretmesi tavsiye edilir. Asıl felaketlere sabredenlerin insan olduğu vurgulanır. $\mathrm{O}$ arada çocuk vefat eder, anne feryat eder. Burada yaşam hakkı, hastalık, ölüm, insanın sınanması, sabır değeri üzerinde durulmaktadır. 
Bebek yahut Hakk-ı Karar şiirinde, M. Akif’in iki kızı Cemile ve Feride, hotozlu oyuncak bebek isterler. Çocuklarını kırmaz akşam bebekleri getirir. Çocuklar sevinir. Beş yaşındaki küçük Feride uyumaz, bütün gece bebeğiyle oynar. Sonra uyur. Uyanır, bebeğiyle oynar, bebeği döver, sonunda bebeği kırar! Yedi yaşındaki Cemile’nin bebeği ise sağlamdır. Feride, ablasının bebeğini ister, Cemile vermek istemez, babasının isteği ile verir. Eğer bu bebeği kırarsa, babası yenisini alacaktır. Feride oynar, geri verir, sonra yine ister, çabuk geri vermesi koşuluyla Cemile yine verir. Babası böyle bir söz söylemiştir. Oyun bitince geri alır. Üçüncü sefer de, babası Feride’nin yalvaracağını sanırken, Feride doğrudan ‘bebeğini’ ister!

\section{“Bebeğmi ver!” demesin mi üçüncüsünde kıza? \\ Mĕ̆er hukuk da bilirmiş bakın şu saygısıza!.. (Ersoy, 1984, 150)}

Burada Mehmet Akif'in iyi bir baba olduğunu görmekteyiz. Çocuklarını seven, çocuklarına güzel davranan, çocuklarına oyuncak alan, onların oynamasını izleyen, kimi zaman onların oyununa katılan, anlaşmazlıkları çözen, arabulucu bir rol oynadığına şahit oluyoruz. Oyunun kurallarını çocuklarının mantığına göre, onların görüşünü alarak kurabilmektedir. Çocuk psikolojisini bilmekte, çocuk haklarına riayet etmektedir. Çocuk psikolojisinin bilinmesi günümüz eğitim bilimleri bulguları ile uygundur. Çocuk Hakları Sözleşmesi ise Birleşmiş Milletlerde 1989 yılında kabul edilmiş, Türkiye'de 1995 yılından itibaren uygulamaya geçilmiştir. Çocuk hakları bizim kültürümüzde vardır, uygulanmıştır. Olayda ayrıca küçük Feride'nin hakkını bildiği ve savunduğu görülmektedir. Her ne kadar çocuk psikolojisiyle hareket etse de, çocukların da haklarını ve sorumluluklarını bilmesi günümüzde arzu edilmektedir.

\subsection{Değerler Eğitimi İle İlgili Örnek Olaylar}

Değer, "bir şeyin arzu edilebilir veya edilemez olduğu hakkındaki inanç" olarak tanımlanabilir (Güngör, 1993, 27). Değerler ailede, okulda, toplumda eğitim olarak verilebilir. Okullarda Sosyal Bilgiler dersi içeriğinde birçok değer bulunmaktadır. Adil olma, aile birliğine önem verme, bağımsızlık, barış, bilimsellik, çalışkanlık, dayanışma, duyarlılık, dürüstlük, estetik, hoşgörü, misafirperverlik, özgürlük, sağlıklı olmaya önem verme, sevgi, sorumluluk, saygı, temizlik, vatanseverlik, yardımseverlik değerleri eğitim yoluyla verilmektedir (Selanik Ay, 2006, 22 vd.). İlköğretim Din Kültürü ve Ahlak Bilgisi dersi (4-8. Sınıflar) öğretim programında; 
alçak gönüllülük, bağışlama, cesaret, cömertlik, doğa sevgisi, doğal çevreye duyarlılık, doğruluk, dostluk, emaneti korumak, fedakârlık, gazilik, görgülü olmak, güvenirlik, hakseverlik, hakikat sevgisi, hayâ, ibadet yerlerine saygı, iffet, iyi niyet, kadirşinaslık, kanaat, kardeşlik, merhamet, millet sevgisi, milli birlik şuuru, mürüvvet, namuslu olmak, nezaket, ölçülülük, paylaşımc1 olmak, sabır, sadelik, samimiyet, sözünde durmak, şehitlik, şükür, tarihsel mirasa duyarlılık, tutumluluk, Türk büyüklerine saygı, vefa değerleri yer almaktadır (Şimşir ve Dilmaç, 2016, 192193). Bu değerler Hayat Bilgisi, Vatandaşlık ve Demokrasi Eğitimi, Türkçe, Tarih, Coğrafya, Felsefe, Kimya, Beden Eğitimi, Matematik, Müzik, Görsel Sanatlar derslerinde genişletilerek değerlerin eğitimi yapılmaktadır (Şimşir ve Dilmaç, 2016, 193-196). Tarihi şahsiyetleri ve eserlerinin kullanılması değerlerin kazandırılmasına katkı sağlayacaktır (Köç, Demirkaya, Ünal, 2020, 98).

Mehmet Akif, Safahat adlı eserinde şiirlerinde örnek olaylara yer vererek değerler eğitimi yapar, okuyucuyu güdüler. Durmayalım adlı şiirde Sa'di Şirazi'den bir hikâye anlatır. Bir gece kervanla çölde giderken, yorulsalar da istirahati terk edip yola devam etmişler. Sa'di ise yorgunluktan uyuyup kalmış. Deveci O’nu uyandırmış ve amaca ulaşmak için devam et demiş. Ferhad'dan örnek alınmasını istemiş:

İbret al erbâb-ı ikdâmın bakıp âsârına:

Dă̆ dayanmaz erlerin dă̆lar söken ısrârına. (Ersoy, 1984, 29)

Mazi yani geçmişin dehşetli bir dikenlik olduğunu, istikbal yani geleceğin korkusuz ve mübarek bir toprak olduğu konusunda teşbih yapar. 'İnsan için ancak çalıştığı vardır' (Necm, 39Karaman vd., 2006, 526). Yerin, göğün çalıştığını, Yaratıcının bile boş durmadığını ve çalışılması gerektiğini söyler.

Ey, bütün dünyâ ve mâfihâ ayaktayken, yatan!

Leş misin, davranmıyorsun? Bâri Allah'tan utan! (Ersoy, 1984, 31)

Vaiz Kürsüde şiirinde, Sadi'den çalışma değeri ile ilgili bir hikâye daha anlatır. Kalender meşrepli biri sabahleyin sabahtan yola çıkar, nasibini kırda arar. Akşam olur, köyüne dönemez, ağaca tırmanır. Bakar, kötürüm bir tilki inler, açtır. Biraz sonra bir aslan, ağzında ceylan ile gelir. Aslan ceylanı yer, kalanı bırakır gider. Kötürüm tilki sürünerek gelir ve kalan eti yer. Bunun üzerine kalender köylü, çalışmayıp tevekkül ederse rızkının geleceğini düşünür. Ertesi gün bir 
mağaraya gizlenir. Üç gün bekler, gelen giden yoktur. Çaresiz yatarken çalışması gerektiği söyleyen bir ses işitir.

"Dolaş da yırtıcı arslan kesil, behey miskin!

Niçin yatıp, kötürüm tilki olmak istersin?

Elin, kolun tutuyorken çalış, kazanmaya bak!

Ki artı̆̆ınla geçinsin senin de bir yatalak.” (Ersoy, 1984, 274)

Mehmet Akif, bir eğitimci olarak bize ders verir ve çalışma değerini delilleriyle ortaya koyarak okuyucuya kazandırmaya çalışır. Çalışma değerinde hazırcılık yerine el emeği, alın teri, gayret vardır. Kazanılanları ihtiyaç sahipleriyle paylaşmak onur verici bir davranıştır.

Hasbihal şiirinde, bu günün işini yarına bırakma denir. Çalışma değeri vurgulanır.

"Geçen geçmiştir artık; ân-ı müstakbelse mübhemdir;

Hayâtından nasîbin: Bir şu geçmek isteyen demdir."

Sakın ey nûr-i dîdem, geçmesin beyhûde eyyâmın;

Çalış hâlin müsâidken... Bilinmez çünkü encâmın.

Diyor Kur'an: "Bilenler, bilmeyenler bir değil. Heyhât

Nasıl yeksân olur zulmetle nûr, ahyâ ile emvât!” (Ersoy, 1984, 145-146)

Mezarlık şiirinde, mezarlığın tefekkür yerini olduğunu, mezarlıkta babasının başında Kur'an okuyan çocuğun hayatı, babasının mezarının ise ölümü tasvir ettiğini, İlahi kudretin zltlıkta tecelli ettiğini açıklar.

Çocuk hayâta, o makber de mevte bir levha.

Tezâd-ı kudreti gör: Bak şu levh-i zîrûha! (Ersoy, 1984, 48)

Çocuğun babasının mezarını ziyaret etmesini ve başında güzel bir şekilde Kur'an (Tebareke) okumasını onaylar. Burada ölülere değer verme, ruhlarına Kur'an okuyup gönderme değeri vardır.

Azim şiirinde Sa'di'yi bizim Doğu'nun kemal ruhu olarak taktim eder ve ondan bir hakikat dersi verir: Hikâyede beş-on kafile yola çıkmış, gündüz gitmiş ve gece olunca bir yere varmışlar. Orada evladını kaybeden bir baba görmüşler, her çadıra tek tek gidip oğlunu sormuş. Hatta çöle doğru bir taş bile görse oğlu olabilir diye gidip bakmış. Koskoca yerde çocuğunu nasıl bulacak diye düşünürken, bakmışlar ki adam çocuğunu elinden tutarak getiriyor! Anlatmış: 
Evladımı buldum ama sen bana sor. Karşımda ne görsem $\mathrm{O}$ olabilir diyerek koştum, baktım. $\mathrm{Bu}$ durum binlerce kez beni aldatsa da bundan vazgeçmedim. Azmettim, hiç ümitsizliğe düşmedim. Sonunda çocuğuma kavuştum.

Bir gâye-i maksûda şitâb eyleyen âdem,

Tutmuşsa bidâyette ĕger azmini muhkem,

Er geç bulacak sa'y ile dil-hâhını elbet.

Zîrâ bu şu'un-zâr-ı tecellîde, hakîkat, (Ersoy, 1984, 66)

Bir amaç uğrunda koşan kimse, başlangıçta azim ve teşebbüsünü sağlam tutmuşsa elbette gönlünün istediğini er geç bulacaktır. Çaba ve Allah'ın yardımı birbirine âşıktır! İstek, azim ve hareket birlikte olsun, tevfikin meydana gelmemesine imkân yoktur. Ümitsizliğin sonu yoktur, ona düşenler ebediyyen hüsrandan çıkamaz. Eğer baba ümitsizliğe düşseydi ne olurdu?

Vazgeçmiş olaydı aramaktan, ne bulurdu?

Elbet biri candan, biri cânandan olurdu! (Ersoy, 1984, 67)

Burada azim değeri verilmektedir. Azmedenler hedefe ulaşır. Hem kendi mutlu olur hem de çevresindekilerini mutlu eder. Ümitsizliğe düşenler her şeylerini kaybedebilir. Azmetmek kolay değildir, iki-üç başarısızlık ümit yolunu kapatabilir. Azimle engeller aşılır.

Seyfi Baba şiirinde çalışmak, yaşlılığı iyi geçirmek ve yardımlaşma değeri üzerinde durulur.

Kim kazanmazsa bu dünyâda bir ekmek parası:

Dostunun yüz karası; düşmanının maskarası! (Ersoy, 1984, 71)

Yaşlıların emeklilik hakkı, emekliliğini yaşaması istenir.

Yoksa yetmiş beşi geçmiş bir adam iş yapamaz;

Ona ancak yapacak: Beş vakit abdestle namaz. (Ersoy, 1984,71)

Mehmet Akif Seyfi babaya para yardımı yapmak ister ama kesesine bakar ki para yok, buna üzülür.

O zaman koptu içimden şu tehassür ebedî:

Ya hamiyyetsiz olaydım, ya param olsa idi! (Ersoy, 1984, 71)

Vahdet şiirinde fedakârlık değeri üzerinde durur. Huzeyfet-ül Adevi'nin hikâyesini anlatır. Yermuk Savaşı'nda su vermek istediği amcasının oğluna, başka bir yaralının inlemesi 
üzerine, amcaoğlunun suyu o inleyen yaralıya götürmesini istemesi, o yaralıya varınca başka bir inleme üzerine o yaralı da inleyen yaralıya gitmesini ister. Üçüncü yaralıya vardığında şehit olduğunu görür. Acele ikinci yaralıya koşar ama o da şehit olmuştur. İlk yaralıya geldiğinde ise o da şehit olmuştur. Burada kendi ihtiyaç sahibi iken, başkasını kendine tercih etme vardır. Çağımızın hastalığı bencilliğin tam tersi bir değerdir. Akif bu günkü durumu ortaya koyar:

Şark'ın ki mefahir dolu, mazi-i kemali,

Ya Rab, ne onulmaz yaradır şimdiki hali! (Ersoy, 1984, 486)

\subsection{Türk Milli Eğitimin Temel İlkeleri İle İlgili Örnek Olaylar}

Türk milli eğitimin sisteminde on dört temel ilke benimsenmiştir. Bunlar arasında genellik ve eşitlik, ferdin ve toplumun ihtiyaçları, yöneltme, eğitim hakkı, fırsat ve imkân eşitliği, süreklilik, planlılık, okul ile ailenin işbirliği, her yerde eğitim bulunmaktadır (Şişman ve Taşdemir, 2008, 36-38). Mehmet Akif eğitimle ilgili örnek olaylarında milli eğitimin temel ilkelerine yer vermektedir.

Küfe başlıklı şiirinde evden çıktığında sokakta eski bir hamal küfesiyle karşılaşır, acaba kimin diye düşünürken, 13 yaşlarında bir çocuk (Hasan) gerilir ve küfeye bir tekme indirir. Kızgınlıkla, babasının o küfe altında öldüğünü söyler. Annesi küfenin kırılmasına engel olur, ekmek parasını bununla kazanacağını belirtir. Mehmet Akif de anneyi destekler. Çocuk O’na da tepki verir. Ancak Mehmet Akif çok olgunlukla yaklaşır ve çocukla iletişime geçer, çocuğu güdüler. Çalışmanın ayıp ya da günah olmadığını, dilenciliğin ayıp olduğunu ifade eder.

Kuzum, ayıp mı çalışmak, günah mı yük taşımak?

Ayıp: Dilencilik, işlerken el, yürürken ayak. (Ersoy, 1984, 25)

Çocuk ise okumak istediğini, hamallığı istemediğini belirtir. Mehmet Akif işi olduğu için oradan ayrılır ama Hasan’ı merak eder. Sonra ki günlerde Fatih’te çocuğunu gezdirirken Hasan’1 hamallık yaparken görür. Yetimin hali perişandır. O sırada ortaokuldan çıkan 50'den fazla çocuk ile Hasan karşılaşır. Çocuklar öğrenci oldukları için mutludur. Hasan ise okula gidememiştir ve 'küfe mahkûmu’ mecburi olarak o yükü ölünceye kadar taşıyacaktır.

O, yük değil, kaderin bir cezâsı ma 'sûma...

Yazık, günâhı nedir, bilmeyen şu mahkûma! (Ersoy, 1984, 27) 
Örnek olayda Milli Eğitim Temel Kanunu ilkelerinden genellik ve eşitlik ile imkân ve firsat eşitliği ilkelerinden mahrum kalan çocuğun hikâyesi anlatılmaktadır.

Mehmet Akif bir ressam gibidir, şiirle resim çizer. Toplumu, aileleri tasvir eder, anlatır, fertleri çizer. Meyhane başlıklı şiirde bir aile dramını gözler önüne serer. Mehmet Akif gözlem yapar, meyhaneyi ziyaret eder. İçki içen birinin eşi yanında bir komşu ile gelir. Kadın, eşine sitemler eder, evde yaşayanların aç kaldığını, kızlarının evlenme çağına geldiğini ama istemeye geleceklerin soruşturmada 'sarhoşun kızı' olduğu söylenince vazgeçtiklerini, oğlunun da okul aylıkları ödenmediği için kovulduğunu, üç gündür eve gelmediği için babasını istediğini, diretmesine dayanamayarak geldiğini söyler. Adam ise kadını çok konuştuğu için boşar, kadın bayıllir.

Necip de minderi koltukta geldi mektepten...

Demiş ki kalfa: "Sekiz aydır almadim hele ben

Ne haftalık, ne de aylik... Senin baban olacak

Kumarcl, oğlu için az yesin de tutsun uşak!"

Kovuldum anne! deyip ăğlyor zavallı çocuk...

Ne yapsin annesi? Dünyâda bir güvendiği yok! (Ersoy, 1984, 42)

Olayda aile görevini yerine getirmeyen babanın ailesine verdiği zarar olduğu gibi ortaya konulmuştur. Aile bireylerinin yaşama hakkı tehlikeye girmiş, kızın evlenme hakkı kaybolmuş, çocuğun eğitim hakkı elinden alınmış, sevgi hakkı ise karşılık görmemiştir.

Köse İmam şiirinde halkın eğitimle uyandırılacağını belirtir ve öncelikle insanlığın öğretilmesini ister.

Dinledin, gördün a oğlum. Ne bozuk terbiyemiz!

Ne yapıp yapmalı, insanlı̆̆ ögretmeliyiz. (Ersoy, 1984, 129)

Burada milli eğitim ilkelerinden halk eğitimi, eğitim hakkı, genellik ve eşitlik ve insan hakları eğitimi vurgulanmaktadır. Eğitim ülkenin tamamına yayılmalı ve herkesi kapsamalıdır.

Husran-ı Mübin adlı nazım parçasında okula başladığı gün babasının 'insan olur ilerde', annesinin ise paşa olmasını istediğini, ancak çalışmasının anne-babasının istediğinin aksine ara yerde kaldığını belirtir. 
Âmâli tezâd üzre giderken ebeveynin,

Hep böyle harâb olmada etfâl ara yerde! (Ersoy, 1984, 135)

Burada milli eğitim ilkelerinden yöneltmenin ne kadar önemli olduğu görülmektedir. Anne paşa olmasını isterken baba daha geniş düşünerek insan olmanın daha önemli olduğunu düşünmektedir. Mehmet Akif ise bu amaçlara ulaşamadığını dile getirir. Oysa kendisi hem veteriner, hem milletvekili, hem öğretmen, hem de milli şairimiz olmuştur. Ayrıca Türk ve İslam dünyasının en önde gelen edebiyatçılarından biridir. Yaşamı ile insanlık için örnek bir şahsiyettir.

Amin Alayı şiirinde okula giden çocukların neşesini, sefasını, kafile, tabur halinde yürüyüşünü tasvir eder, kafileyi şanlı ordu olarak görür.

Girer diyâr-ı meâlîye doğrudan doğru.

Bu ancak işte, eğer varsa, şanlı bir ordu! (Ersoy, 1984, 144)

Bu güzel alayın önüne çıkan bir arabayı ve içindekilere ikaz ederek 'geleceğin' önünü kesmemeleri istenir.

Burada milli eğitimin eğitim hakkı, genellik ve eşitlik ilkeleri yer almaktadır. Âmin alayı çocukların okula özendirilmesi, okuma sevgisi, okul korkusunun yenilmesi, eğitime, okula, öğretmene ve öğrenciye saygı değerlerini de taşımaktadır (Akyüz, 2020, 89). Mehmet Akif de eğitime ve okula karşı iyi bir güdüleyicidir.

Vaiz Kürsüde şiirinde, esir olan bir milletin yani Almanya'nın hikâyesini anlatır. Akıl sahiplerinden seçilme bir heyet, milletin kurtuluşuna çare düşünür. Kimi askerin, kimi donanmanın, kimi ilme önem vermenin, kimi sanata kimi paraya önem vermenin çözüm olacağını söyler. Bir ihtiyar ise mahalle mektebinin gerekli olduğunu dile getirir. Onu sözü pek anlaşılmamış, ancak o açıklamış: Sayılanların hepsi önemlidir. Ancak temeli eğitimdir. Millet okur-yazar yani eğitimli olursa her şey yapılır. Donanma, ordu zorunlu bir ihtiyaçtır. Ancak bu ihtiyacı öğreten öğretmendir.

Donanma, ordu birer ihtiyâc-ı mübrimdir , O ihtiyâcı, fakat, ögreten "muallim"dir?

Deyip karârını vermiş ki, aynen icrâya,

Konunca ortaya çıkmış, bugünkü Almanya. (Ersoy, 1984, 280) 
Sedan'da orduyu Prusya'ya teslim eden Fransızlar, kendilerine karşı savaşanın Prusya ordusu olduğunu, gerçekte ise öğretmen ordusunun zafer kazandığını dile getirir.

"Muallem ordusudur harbeden Prusyall'nın ;

Muallim ordusu, lâkin, asıl muzaffer olan!” (Ersoy, 1984, 281)

Akif'e göre bize lazım olan mahalle mektebidir. Cehaletten kurtulma yoludur. Bunu gerçekleştirebilse idik dış güçlerin maşaları, bize bağlı milletleri isyana kalkışamazdı.

Şu cehlimizle musîbet mi kaldı uğramadık?

Mahalle mektebi lâzım, düşünmeyin artık!

Mahalle mektebi olsaydı bizde vaktiyle,

Ya ŭgrasaydı kalanlar güzelce ta'dîle ;

Yarım pabuçla gezen, donsuz üç buçuk zibidi,

Bir Arnavutluk'u isyâna kaldırır mı idi? (Ersoy, 1984, 281)

Cehaletin çaresi okuldur, zaman ilim zamanıdır. Bilgiden yoksun milletler felaketlere mahkûm olurlar.

Felâketin başı, hiç şüphe yok, cehâletimiz;

Bu derde çâre bulunmaz -ne olsa-mektepsiz.

Ne Kürd elifbeyi sökmüş, ne Türk okur, ne Arab;

Ne Çerkes'in, ne Laz'ın var bakın, elinde kitab!

Hülâsa, milletin efrâdı bilgiden mahrum.

Unutmayın şunu lâkin: “Zaman: Zamân-ı ulûm!” (Ersoy, 1984, 281)

Yapılacak iş mahalle mektebini kurmaktır. Öğretmen ordusu ise planlı olarak yetiştirilmelidir. İhtiyaç fazlası yetiştirilen öğretmen ordusu çekirge orduları gibi ülkeye zarar verir. Öğretmen imanlı, edebli, liyakatli ve vicdanlı olmalıdır.

Mahalle mektebidir işte en birinci adım;

Fakat, bu hatveyi ilkin tasarlamak lâzım.

Muallim ordusu derken, çekirge ordulart

Çıkarsa ortaya, artık hesâb edin zararı!

"Muallimim" diyen olmak gerektir imanl,,

Edebli, sonra liyâkatli, sonra vicdanlı. (Ersoy, 1984, 281)

Gençliğe çağın ilmi öğretilmeli ancak manevi eğitim asla ihmal edilmemelidir.

Evet, ulûmunu asrin şebâba öğretelim;

Mukaddesâta, fakat, çokça ihtirâm edelim. (Ersoy, 1984, 282) 


\section{Sonuç}

Mehmet Akif, Fatih Cami adlı şiirinde kendisi 8 yaşında iken babasının kendisi ve kardeşini yatsı namazına Fatih Camiine götürmesini örnek olay yöntemi ile anlatır. Çocuklar camide özgür bir biçimde oyun oynamakta, şiddet görmemekte, çocukluklarını yaşamaktadır. Bu yaklaşım çocuk gelişim ve eğitimine uygun bir modeldir. Günümüz Türkiye’sinde bu model son yıllarda uygulanmaktadır. Bayram şiirinde, salıncağa parası olmadığı için binemeyen ve ağlayan yetim kız için insanların ricasıyla salıncağa bilmesi tasvir edilir. Çocukların oyun, eğlenme hakkı, mutlu olma, mutlu bir çocukluk geçirme haklarının gerçekleşmesi söz konusudur. Toplum üyeleri bu konuda duyarlıdır. Selma şiirinde 4 yaşında ölen kız kardeşinin yaşama hakkını kaybetmesi tasvir edilir. Yaşam hakkı, hastalık, ölüm, insanın sınanması, sabır değeri üzerinde durulmaktadır. Bebek yahut Hakk-ı Karar şiirinde bir babanın çocuk psikolojisini bilmesi, çocuk haklarına riayet etmesi anlatılmaktadır. Çocuk psikolojisinin bilinmesi günümüz eğitim bilimleri bulguları ile uygundur (Kop, 2017, 369). Ayrıca çocuğun haklarını bilmesi ve savunması Çocuk Hakları Sözleşmesi’nin istediği bir eğitimdir.

Durmayalım adlı şiirde çalışma değeri üzerinde durulmuştur. Amaca ulaşmak için sürekli çalışmak gerekir. İnsan ancak çalışmasının karşılığını elde eder. Evren gözlendiğinde gökyüzünün hareket halinde olduğu görülmektedir. Yeryüzü incelendiğinde ise sürekli bir oluş, yaratılış, hareket içinde olduğu belirtilebilir. Yüce Yaratıcı da sürekli yaratmakta, evreni en güzel şekilde yönetmektedir. Yapılacak iş durmamak, yılmadan yorulmadan çalışmaktır (Emer, 2014, 56 vd.; Uslu, 2015, iv; Yılmaz, 2017, 82). Vaiz Kürsüde şiirinde el emeği ile kazanmanın ve ihtiyacı olanlarla paylaşmanın, yardım etmenin çok değerli olduğunu açıklar (Emer, 2014, 361 vd.). Hasbihal şiirinde çalışma değeri üzerinde bir kez daha durulur. Mezarlık şiirinde, ölülere saygı, mezar ziyareti, onların ruhuna Kur'an okuma değerleri yer alır. Çocuklara bu değerler kazandırılmalıdır. Azim şiirinde çocuğunu çölde kaybeden bir babanın yılmadan, yorulmadan, gayreti, çabası sonucu çocuğunu bulması anlatılır. Azim değerinde, azmedenler hedefe ulaşır (Emer, 2014, 30). Hem kendi mutlu olur hem de çevresindekilerini mutlu eder. Ümitsizliğe düşenler her şeylerini kaybedebilir. Azimle karşımıza çıkan engeller aşılır. Seyfi Baba şiirinde çalışmak, yaşlılığı iyi geçirmek ve yardımlaşma değeri üzerinde durulur. Yaşlılara hak ettiği 
sosyal güvenlik hakkı ve değerleri verilmelidir. Vahdet şiirinde fedakârlık değeri üzerinde durulur. Mehmet Akif örnek olaylarında okuyucuları güdüler adeta harekete geçirir.

Mehmet Akif, Küfe başlıklı şiirinde evden çıktı̆̆ında sokakta karşılaştı̆̆ çocuk hamal Hasan'ın yaşamını ve ona yaklaşımını örnek olay olarak sunar. Küçük Hasan okumak istemiş fakat babasının vefatı nedeniyle baba mesleği olan hamallığ durum Milli Eğitim Temel Kanunu ilkelerinden genellik ve eşitlik ile imkân ve fursat eşitliği ilkelerinden mahrum kalma ile ilgilidir. Hamal Hasan çok istemesine rağmen bu haklarını kullanamamıştır. Ancak Mehmet Akif onun psikolojisine uygun konuşmuştur (Kop, 2017, 369). Meyhane başlıklı şiirde de bir babanın aile görevlerini yerine getirmemesi nedeniyle oğlu Necip'in okuldan kovulması ile eğitim hakkını kullanamaması söz konusudur (Yılmaz, 2017, 105). Ayrıca çocuk babasından görmesi gereken sevgi hakkından yoksun kalmıştır. Köse İmam şiirinde halk eğitimi ve insan hakları eğitimi vurgusu ön plandadır (Uslu, 2015, 77-78). Husran-ı Mübin adlı nazım parçasında milli eğitim ilkelerinden yöneltmenin önemini açıklar. Amin Alayı şiirinde milli eğitim ilkelerinden eğitim hakkı, genellik ve eşitlik ilkeleri yer almaktadır. Gelecek eğitimle ve eğitim sevgisiyle olacaktır (Kop, 2017, 371). Vaiz Kürsüde şiirinde milli eğitim ilkelerinden, halk eğitimi, eğitim hakkı, genellik ve eşitlik, zorunlu eğitim, süreklilik, her yerde eğitim, bilimsellik ilkeleri yer almaktadır (Uslu, 2015, 56). Öğretmen yetiştirme çok önemlidir, öğretmenle gelecek imar edilir. Öğretmen ihtiyaç oranında yetiştirilmeli, planlılık ilkesine bağlı kalınarak kaliteden taviz verilmemelidir (Uslu, 2015, iv; Keskin, 2005, 7). Gençlik milli ve manevi değerlerle işlenmelidir.

\section{KAYNAKÇA}

Akbaş, A. (2013). Safahat. İstanbul: Beyan Yayınları.

Akyüz, Y. (2015). Türk Eğitim Tarihi. Ankara: PegemA Yayınları.

Borich, G. D. (2017). Etkili Öğretim Yöntemleri. (Çeviri Editörü: Bahaddin Acet). Ankara: Nobel Akademik Yayıncılık.

Cengizhan, S. (2015). Öğretim Yöntemleri. Öğretim İlke ve Yöntemleri. (Editör: Tuğba Yanpar Yelken). Ankara: Anı Yayınc1lık, 253-286.

Emer, A. M. (2014). Safahat’ta Değerler Eğitimi Unsurları. Yayınlanmamış Yüksek Lisans Tezi. Yıldırım Beyazıt Üniversitesi, Sosyal Bilimler Enstitüsü, Ankara.

Ersoy, M. A. (1984). Safahat. (Tertip Eden: Ömer Rıza Doğrul). İstanbul: İnkılap ve Aka Kitapevleri. 
Hesapçığlu, M. (1998). Öğretim İlke ve Yöntemleri. İstanbul: Beta Basım Yayım Dağıtım.

Güngör, E. (1993). Değerler Psikolojisi Üzerinde Araştırmalar. İstanbul: Ötüken Neşriyat.

Kacar, İ. (1989). Eğitimci Yönüyle Mehmet Akif. Konya: Esra Yayınları.

Kaplan, M. (2012). Şiir Tahlilleri-Tanzimat'tan Cumhuriyet'e. İstanbul: Dergâh Yayınları.

Kara, Ö.T. (2014). Türk Dili ve Edebiyatı Dersinde Kullanılan Öğretim Yöntem ve Teknikleri. Türk Dili ve Edebiyatı Ögrretimi. (Editörler: Mehmet Dursun Erdem-Ahmet Akkaya). Ankara: PegemA Yayınları, 75-111.

Karaman, Hayrettin vd (2006). Kur'an-ı Kerim ve Açıklamalı Meali. Ankara: Türkiye Diyanet Vakfi Yayınları.

Keskin, M. (2005). Mehmed Âkif Ersoy'a Göre Doğu'nun Geri Kalmışlığının, Batı'nın Gelişmişliğinin Eğitim-Öğretim İle İlişkisi. Erciyes Üniversitesi Sosyal Bilimler Enstitüsü Dergisi, Say1: 18 Y11: 2005/1, 1-14.

Kop, Y. (2017). Safahat'a Göre Mehmet Akif'in Eğitim Anlayışı. Mehmet Akif Ersoy Üniversitesi Eğitim Fakültesi Dergisi, Y11: 2017 Sayı: 41 Sayfa: 363-377.

Köç, A. Demirkaya, H. Ünal, O. (2020). Sosyal Bilgiler Eğitiminde Değerler Eğitimi Açısından Mehmet Akif ve Safahat. Uluslararası Sosyal ve Eğitim Bilimleri Dergisi, Cilt 7, Sayı 13, Haziran 2020, 98-118.

Kösterelioğlu, İ. (2018). Öğretim Yöntemleri. Öğretim İlke ve Yöntemleri. (Editör: Ali ArslanCevat Eker). Ankara: Nobel Akademik Yayınc1lık, 119-146.

Savaş, B. (2014). Öğretim Yöntemleri. Öğretim Illke ve Yöntemleri. (Editör: Mehmet Arslan). Anı Yayınc1lı, Ankara, 153-171.

Selanik Ay, Tuğba, (2016). Okulda Değerler Eğitimi. Farklı Yönleriyle Değerler Eğitimi. (Editörler: Refik Turan-Kadir Ulusoy). Ankara: PegemA Yayınları, 17-40.

Şimşir, Zeynep ve Dilmaç, Bülent (2016). Okullarda Değerler Eğitimi. Değerler Bilançosu, Beyaz Kitap, Sosyoloji, Felsefe, Ekonomi, Eğitim, İletişim, Müzik, Tip. (Editörler: H. Hüseyin Bircan-Bülent Dilmaç). Çizgi Kitabevi Yayınları, 185-207.

Şişman, M. ve Taşdemir, T. (2008). Türk Eğitim Sistemi ve Okul Yönetimi. Ankara: PegemA Yayınları.

Tan, Ş. (2006). Öğretimi Planlama ve Değerlendirme. Ankara: PegemA Yayınları.

Uslu, E. M. (2015). Mehmet Akif Ersoy'un Safahat Adlı Eserinde Eğitim Olgusu. Yayınlanmamış Yüksek Lisans Tezi. Çanakkale Onsekiz Mart Üniversitesi, Eğitim Bilimleri Enstitüsü. Çanakkale. 
Yıldırım, A. ve Şimşek, H. (2008). Sosyal Bilimlerde Nitel Araştırma Yöntemleri. Ankara:

Seçkin Yayıncılık.

Yılmaz, R. (2017). Ortaokul Sosyal Bilgiler Eğitiminde Safahat'ın Değerler Eğitimi Açısından İncelenmesi. Yayınlanmamış Yüksek Lisans Tezi. Necmettin Erbakan Üniversitesi Eğitim Bilimleri Enstitüsü. Konya. 